\title{
COMUNICACÕES
}

\section{Occurrence of basil leaf spot caused by Pseudomonas cichorii in Bahia State, Brazil}

\author{
Zayda Piedad Morales Moreira ${ }^{1}$, Patricia Oliveira dos $\operatorname{Santos}^{1}$, Thiago Alves Santos de Oliveira ${ }^{1}$, Jorge Teodoro de Souza ${ }^{2}$
}

${ }^{1}$ Recôncavo da Bahia Federal University, CCAAB, 44380-000 Cruz das Almas, BA; ${ }^{2}$ Lavras Federal University, Phytopathology Department, 37200-000 Lavras, MG

Author for correspondence: Jorge Teodoro de Souza (jgeteodoro@gmail.com)

Data de chegada: 16/10/2014. Aceito para publicação em: 19/12/2014.

$10.1590 / 0100-5405 / 2041$

Basil (Ocimum basilicum) belongs to the Lamiaceae family and is widely distributed in tropical areas. This herb has medicinal properties and is a source of essential oils (Burgess et al., 1986. http://fshs.org/ proceedings-o/1986-vol-99/249-251\%20(BURGESS).pdf), but its main use is for culinary purposes. There are several diseases that may cause damage to basil. Fusarium wilt (Fusarium oxysporum f. sp. basilicum), gray mold (Botrytis cinerea), damping off or root rot (Rhizoctonia solani; Pythium spp.) and downy mildew (Peronospora belbahrii) are caused by fungi and Oomycetes (Tran, 2011. http://plantclinic. cornell.edu/factsheets/basildiseases.pdf). Leaf spot is caused by the bacterium Pseudomonas cichorii (Burgess et al., 1986. http://fshs.org/ proceedings-o/1986-vol-99/249-251\%20(BURGESS).pdf). Of these diseases, only two have been reported for Brazil: Fusarium wilt was reported for the Federal District (Reis et al., 2007. http://www.scielo.br/ scielo.php?pid=S0100-54052007000200006\&script=sci_arttext) and Pseudomomas cichorii for São Paulo State (Destéfano et al., Revista de Agricultura, v.78, n.1, p.37-48, 2003).

Basil samples showing leaf spot symptoms were collected from a garden at Cruz das Almas (12 39 $19^{\prime} 11^{\prime \prime}$ S- 39 $\left.9^{\circ} 7^{\prime} 19^{\prime \prime} \mathrm{W}\right)$, Bahia State, in April 2013. At this time of the year, temperature is mild and humidity is high. Symptoms occurred on all aerial parts of infected plants, including leaves, petioles and stems. Spots were dark brown and had irregular shape and variable size. Isolations were performed on nutrient agar medium (NA), from where glossy, smooth and translucent bacterial colonies were obtained. One strain, named BR02, was chosen for subsequent characterization. A hypersensitivity test was performed on tobacco plants by inoculating leaves with a cell suspension $\left(10^{7}\right.$ cells. $\left.\mathrm{mL}^{-1}\right)$. Pathogenicity tests were done by spraying healthy basil plants that were incubated for $48 \mathrm{~h}$ at $26^{\circ} \mathrm{C}$ in a moist chamber. Hypersensitive response (HR) was noticed at $24 \mathrm{~h}$ after injection $\left(10^{7}\right.$ cells. $\left.\mathrm{mL}^{-1}\right)$ in tobacco leaves (Figure 1A). Typical leaf spots developed on inoculated plants in $36 \mathrm{~h}$ (Figure 1B), but not on non-inoculated control plants. The bacterium was re-isolated from diseased plants and was identical to the inoculated strain.

For taxonomic characterization, a fragment of the small subunit of the ribosomal RNA (16S rRNA) of strain BR-2 was amplified and sequenced in an ABI PRISM 3100 sequencer (Life Technologies),

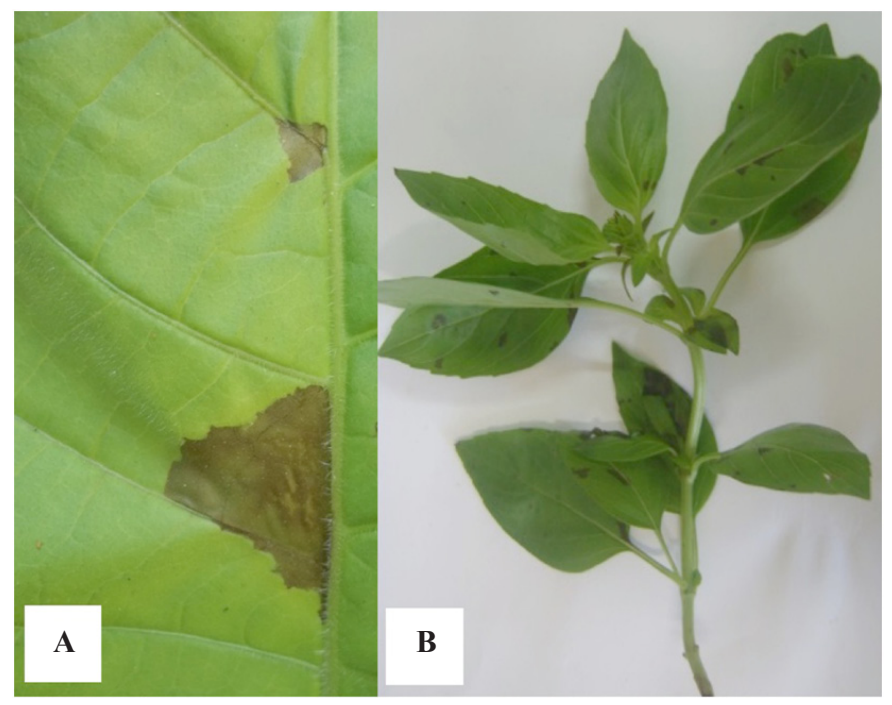

Figure 1. (A) Tobacco leaf showing hypersensitive response at $24 \mathrm{~h}$ after injection with a cell suspension of Pseudomonas cichorii. (B) Typical leaf spots developed on inoculated basil plants at $36 \mathrm{~h}$ after inoculation.

according to Barretti et al. (2012) (http://link.springer.com/article/10 $.1007 \% 2$ Fs 13313-011-0107-1). The obtained sequences were joined and edited with the software BioEdit v.7.2 (http://www.mbio.ncsu. edu/bioedit/bioedit.html). The sequenced fragment was $1,367 \mathrm{bp}$-long and $100 \%$ identical to sequences of four strains of $P$. cichorii deposited in public databases under numbers AB724287.1, AB724286.1, AB724283.1, JF951725.1. The sequence obtained from strain BR02 was deposited in EMBL under accession number LN555732. That strain was identified as Pseudomonas cichorii and deposited in the Culture Collection of Microorganisms of Bahia under reference number CCMB562. This is the first report on the occurrence of basil bacterial leaf spot in Bahia State.

Acknowledgement

JTS acknowledges CNPq for the productivity scholarship. 